\title{
Technical viability of the production of sweet potato plantlets in trays
}

\section{Viabilidade técnica da produção de mudas de batata-doce em bandejas}

\author{
Amarílis Beraldo Rós ${ }^{1}$; Sônia Maria Nalesso Marangoni Montes²; Nobuyoshi \\ Narita $^{2}$; João Tavares Filho ${ }^{3 *}$
}

\begin{abstract}
The cultivation of sweet potato requires high amount of stems per area unit and the rooting of minicuttings can contribute to the production of large number of plants in a short time. Thus, this study aimed to investigate the technical viability of plantlets production of sweet potato in trays. The treatments consisted of mini-cuttings (segments with two nodes removed from the middle and upper thirds of branches) of 30 clones of sweet potato which were grown for 35 days in trays and then transplanted to a permanent site. The experimental design was completely randomized with four replications. The following characteristics were evaluated: percentage of rooting and survival of plantlets after transplanting. The average mini-rooted cuttings was approximately $95 \%$. The survival rate of the clones in the field was above $98 \%$. It was concluded that it is technically viable the production of sweet potato in trays.
\end{abstract}

Key words: Ipomoea batatas (L.) Lam., rooting, cutting, propagation

\section{Resumo}

O cultivo de batata-doce exige elevada quantidade de ramas por unidade de área e o enraizamento de miniestacas pode contribuir para a produção de grande quantidade de mudas em pouco tempo. Assim, esse trabalho teve por objetivo verificar a viabilidade técnica da produção de mudas de batata-doce em bandejas de isopor. Os tratamentos foram constituídos de mini-estacas (segmentos com dois nós removidos dos terços médio e superior de ramas) de 30 clones de batata-doce os quais foram cultivadas por 35 dias em bandejas sendo, em seguida, transplantadas para o local definitivo. O delineamento experimental foi inteiramente casualizado, com quatro repetições. As seguintes características foram avaliadas: percentagem de enraizamento e sobrevivência das mudas após transplantio. A média de mini-estacas enraizadas foi de aproximadamente $95 \%$. A taxa de sobrevivência dos clones no campo foi superior a $98 \%$. Concluiu-se que é tecnicamente viável a produção de mudas de batata-doce em bandejas.

Palavras-chave: Ipomoea batatas (L.) Lam., enraizamento, estaca, multiplicação

Eng $^{\mathrm{a}}$ Agr $^{\mathrm{a}}$, Doutoranda do Curso de Agronomia. Universidade Estadual de Londrina, UEL. Londrina, PR. Pesquisadora Científica da APTA-Pólo Alta Sorocabana. Cx. Postal 298, 19015-970, Presidente Prudente, SP. E-mail: amarilis@apta.sp.gov.br

2 Eng ${ }^{\text {o. Agr }}{ }^{\circ}$, Drs., Pesquisadores Científicos, APTA-Pólo Alta Sorocabana. Cx. Postal 298, 19015-970, Presidente Prudente, SP. E-mail: soniamontes@apta.sp.gov.br; narita@apta.sp.gov.br

3 Prof. Associado C do Dept ${ }^{\circ}$ de Agronomia da Universidade Estadual de Londrina, UEL. Cx Postal 6001, 86051-990, Londrina, PR. E-mail: tavares@uel.br

* Autor para correspondência

Recebido para publicação 22/07/2010 Aprovado em 16/07/2011 


\section{Introduction}

The propagation of the sweet potato is via non-rooted cuttings (about $0.3 \mathrm{~m}$ of terminal branch cutting with 7 to 8 unfolded leaves). However, the use of non-rooted vegetative propagules may result in an inadequate final stand. According to Brune, Silva and Freitas et al. (2005), replanting is necessary when the percentage of branches (vegetative propagules) sprouted does not reach the minimum $85 \%$. The amount of plants per hectare varies from 16,600 to 66,600 (EMBRAPA, 1995). This means that the yield of rooted cuttings must contemplate the production of large amounts of plantlets in little areas, at low costs, and preferably requiring the smallest amount of branches, therefore producing more healthy and productive plants.

The rooting of cuttings is frequently used in the cultivation of fruits and flowers. Its use is due mainly to the need of plantlets with traits of the mother plant (MELETTI et al., 2000; SALOMÃO et al., 2002). Moreover, it allows the obtention of a high number of plantlets from few mother plants in a relatively little space (LIMA et al., 2006) and in shorter period of time when compared with the time of development of seedlings from the seeds.

In horticulture, the use of Styrofoam trays is widely studied for several species propagated by seeds. According to Reghin et al. (2007), the production of seedlings in trays allows the grower to dedicate more attention to the plants, since the activity is developed in protected cultivation, favouring the pest and disease controls, besides guaranteeing the high rate of survival after the transplant and more uniformity in the field.

This study aimed to investigate the technical viability of plantlets production of sweet potato in trays.

\section{Material and Methods}

The work was conducted in two stages. Both of them were conducted in the APTA - Agência Paulista de Tecnologia dos Agronegócios - in Presidente Prudente city ( $22^{\circ} 11^{\prime} \mathrm{S}, 51^{\circ} 23^{\prime} \mathrm{W}$, Aw climate) - São Paulo Brazil. The first stage (production of rooted plantlets in trays) was conducted in a greenhouse, from October to December 2007. The second stage was conducted after transplanting to a permanent site, in December 2007. The plants required for production of minicuttings were obtained from plants growing in pots in the nursery. The treatments consisted of mini-cuttings of 30 clones of sweet potato: 1107, 1190, 1194, 1195, 1196, 1197, 1198, 1199, 1202, 1205, 1206, 1208, $1209,1213,1217,1218,1220,1221,1223,1224$, $1225,1226,1227,1228,1229,1230,1231,1232$, 1234 and 1237 . These materials were made available by the sweet potato breeding program developed at the Potato International Centre - CIP - as part of the project AGROSALUD.

Survival analysis in the field of transplanted plantlets of sweet potato was used to assess the feasibility of the technique of production of plantlets in trays. The experimental design for the two phases was randomized blocks with four replications. For the first phase polystyrene trays were used with 72 cells, and each cell measuring 11 centimeters depth by five centimeters wide. The trays were filled with substrate Plantmax ${ }^{\circledR}$ to receive the mini-cuttings and were positioned suspended $0.5 \mathrm{~m}$ above the ground inside the greenhouse. The were produced as follows: segments with two nodes were removed from the middle and upper thirds of each branch (up to $0.6 \mathrm{~m}$ in each of 30 clones). The leaves were trimmed with scissors with the utmost care to not damage the buds. Minicuttings thus formed were immersed for 10 minutes in a solution of $5 \mathrm{~mL} / 50 \% \mathrm{w} / \mathrm{v}$ Carbendazim. The next day, the basal buds of each mini-cutting was inserted into the trays previously filled with substrate Plantmax ${ }^{\circledR}$. The percentage of rooted was assessed 10 and 18 days after planting (DAP) by counting the number of sprouted mini-cuttings in each tray. Minicuttings were considered sprouted with at least one leaf of length equal to or greater than $1 \mathrm{~cm}$. For the second stage, the mini-cuttings were taken from the trays and transplanted to a permanent site, in Alfisol type soil, at $0.3 \mathrm{~m}$ spacing between plants and $0.9 \mathrm{~m}$ between rows 35 days after planting trays. Each plot consisted of three rows of 18 plants each, totaling 54 plants. Only plants 
that survived at least ten days after transplantation were considered for the assessment of plantlet survival. The data were processed by the equation arcsine $(\mathrm{x} / 100)^{1 / 2}$ and submitted to analysis of variance by $\mathrm{F}$ test and means compared by grouping test of Scott-Knott at 5\% probability.

\section{Results and Discussion}

For all traits evaluated it was observed significant differences (Table 1). In mini-cuttings of 25 clones (1107, 1190, 1195, 1196, 1199, 1202, 1205, 1206, $1208,1209,1217,1218,1220,1221,1223,1224,1225$, $1226,1227,1228,1229,1231,1232,1234$ and 1237) it was observed a high percentage of sprouting whose values, regardless of time of assessment (10 DAP or 18 DAP) were above $90 \%$ with exception of the clone 1223 to 18 DAP (Table 1). In the other hand, 11 clones showed $100 \%$ of sprouting and only two clones (1213 and 1197) showed less than 83.5\%. It was also noted that these same clones with the clones 1198 and 1223 showed at 18 DAP sprouting lower than those observed at 10 DAP. This fact is explained by the death of mini-cuttings after the first evaluation, probably due to increased susceptibility to dehydration or low amount of reserves to be used during the process of emission of roots and leaves. In study with Erythrina falcata, Betanin and Nienow (2010) also observed death of rooted cuttings and they explained the fact like dehydration. In the evaluation at 18 DAP, only one clone (1107) showed an increase in the number. It is considered therefore practically $100 \%$ of mini-cuttings rooted and leaves in a period of ten days. The high percentage of rooting of mini-cuttings was probably helped by the use of cuttings taken from young part of the plant, since this part is, according to Hartman et al. (1997), lower levels of lignification and meristematic cells with more active metabolism, which favors the rooting and sprouting.

Rós-Golla et al. (2010) worked with varieties of sweet potato (Uruguaina and Canadense) observed percentage of rooting exceeding $97 \%$ in trays of 72 and 128 cells corroborating the results of this work.
The good performance in the rooting of the minicuttings of herbaceous and bush plants in trays of 72 was proved for several vegetable species, being the use of this recipient consolidated in the production of the plantlets for several ornamental plants between them: calanchoe (GONÇALVES; MINAMI, 1994), chrysanthemum (CUQUEL; GRANJA; MINAMI, 1992), croton (TILLMANN et al., 1994) and hydrangea (LUZ; PAIVA; LANDGRAF, 2007). Being the rooting of the cutting for hydrangea above $95 \%$ when using the trays of 72 with sandy substrate (LUZ; PAIVA; LANDGRAF, 2007).

However, the response to the rooting of the cuttings differs for several plants. In different species of the same genus, it is frequent the difference in the response to the production of viable cuttings. In study with different species of Lippia, Pimenta et al. (2007) observed different behaviours regarding the rooting of the cuttings, considered inadequate for some species as a way of multiplication of materials, while for some other species the rooting was considered satisfactory.

Roncatto et al. (2008) noticed differences among the species of passion fruit with regard to the rooting percentage of the cuttings with tree vegetative buds. The cuttings, kept in plastic trays, have presented rooting percentage varying from 3 to $58 \%$ without using auxin.

A high variability in response to the rooting process is found species of coffee plants. Some materials root easily while in others the cutting practice is not recommended. Such difference of behaviour is found within the same species, in which are found varieties with differences concerning the rooting potential due to factors such cutting type and sampling time of the branches (VILANOVA, 1959, cited for ONO; RODRIGUES, PINHO, 1992). Nevertheless, in coffee, the use of trays for rooting of cuttings with 2 nodes is used, favouring higher production of healthy plantlets and in a shorter period of time (ONO; RODRIGUES, PINHO, 1992). 
Table 1. Percentages regarding the sprouting of the mini-cuttings and the survival in by clones of sweet potato.

\begin{tabular}{|c|c|c|c|}
\hline Clone & Sprouting - 10 DAP ${ }^{1}$ & Sprouting - 18 DAP $^{1}$ & Survival - 10 DAT $^{1}$ \\
\hline & & ------------\%"-------------- & \\
\hline 1195 & $100.0 \mathrm{~A}$ & $100.0 \mathrm{~A}$ & $100.0 \mathrm{~A}$ \\
\hline 1217 & $100.0 \mathrm{~A}$ & $100.0 \mathrm{~A}$ & $99.5 \mathrm{~B}$ \\
\hline 1218 & $100.0 \mathrm{~A}$ & $100.0 \mathrm{~A}$ & $99.0 \mathrm{~B}$ \\
\hline 1220 & $100.0 \mathrm{~A}$ & $100.0 \mathrm{~A}$ & $99.5 \mathrm{~B}$ \\
\hline 1224 & $100.0 \mathrm{~A}$ & $100.0 \mathrm{~A}$ & $100.0 \mathrm{~A}$ \\
\hline 1225 & $100.0 \mathrm{~A}$ & $100.0 \mathrm{~A}$ & $99.9 \mathrm{~A}$ \\
\hline 1226 & $100.0 \mathrm{~A}$ & $100.0 \mathrm{~A}$ & $99.9 \mathrm{~A}$ \\
\hline 1227 & $100.0 \mathrm{~A}$ & $100.0 \mathrm{~A}$ & $100.0 \mathrm{~A}$ \\
\hline 1228 & $100.0 \mathrm{~A}$ & $100.0 \mathrm{~A}$ & $99.9 \mathrm{~A}$ \\
\hline 1229 & $100.0 \mathrm{~A}$ & $100.0 \mathrm{~A}$ & $100.0 \mathrm{~A}$ \\
\hline 1234 & $100.0 \mathrm{~A}$ & $100.0 \mathrm{~A}$ & $100.0 \mathrm{~A}$ \\
\hline 1190 & $99.0 \mathrm{~B}$ & $99.0 \mathrm{~B}$ & $100.0 \mathrm{~A}$ \\
\hline 1231 & $99.0 \mathrm{~B}$ & $99.0 \mathrm{~B}$ & $99.0 \mathrm{~B}$ \\
\hline 1232 & $98.8 \mathrm{~B}$ & $98.8 \mathrm{~B}$ & $98.6 \mathrm{~B}$ \\
\hline 1208 & $98.7 \mathrm{~B}$ & $98.7 \mathrm{~B}$ & $98.8 \mathrm{~B}$ \\
\hline 1202 & $98.2 \mathrm{~B}$ & $98.2 \mathrm{~B}$ & $100.0 \mathrm{~A}$ \\
\hline 1206 & $97.7 \mathrm{C}$ & $97.7 \mathrm{C}$ & $98.6 \mathrm{~B}$ \\
\hline 1199 & $97.2 \mathrm{C}$ & $97.2 \mathrm{C}$ & $98.7 \mathrm{~B}$ \\
\hline 1196 & $97.1 \mathrm{C}$ & $97.1 \mathrm{C}$ & $99.6 \mathrm{~B}$ \\
\hline 1237 & $96.7 \mathrm{C}$ & $96.7 \mathrm{C}$ & $98.3 \mathrm{~B}$ \\
\hline 1209 & $96.7 \mathrm{C}$ & $96.7 \mathrm{C}$ & $96.4 \mathrm{C}$ \\
\hline 1205 & $91.8 \mathrm{D}$ & $91.8 \mathrm{D}$ & $98.3 \mathrm{~B}$ \\
\hline 1107 & $91.7 \mathrm{D}$ & $95.4 \mathrm{C}$ & $97.7 \mathrm{C}$ \\
\hline 1223 & $90.3 \mathrm{D}$ & $87.5 \mathrm{E}$ & $96.4 \mathrm{C}$ \\
\hline 1221 & $90.3 \mathrm{D}$ & $90.3 \mathrm{D}$ & $94.5 \mathrm{C}$ \\
\hline 1230 & $89.0 \mathrm{D}$ & $89.0 \mathrm{D}$ & $89.8 \mathrm{D}$ \\
\hline 1198 & $89.0 \mathrm{D}$ & $87.6 \mathrm{E}$ & $97.4 \mathrm{C}$ \\
\hline 1194 & $83.5 \mathrm{E}$ & $83.5 \mathrm{E}$ & $96.6 \mathrm{C}$ \\
\hline 1213 & $78.5 \mathrm{E}$ & $63.2 \mathrm{~F}$ & $90.9 \mathrm{D}$ \\
\hline \multirow[t]{2}{*}{1197} & $72.2 \mathrm{E}$ & $65.3 \mathrm{~F}$ & $95.1 \mathrm{C}$ \\
\hline & $\mathrm{CV}=3.39 \%$ & $\mathrm{CV}=3.47 \%$ & $\mathrm{CV}=4.12 \%$ \\
\hline
\end{tabular}

Means followed by different letters in the column are different from each other by the test of Scott-Knott, at $5 \%$ of probability. 
Similarly, in Eucalyptus cloeziana, the cuttings obtained through the sprouting of strains have presented different responses to the rooting between the clones used, showing the existence of differences regarding the rhizogenic potential between the clones (ALMEIDA; XAVIER; DIAS, 2007).

Mayer, Pereira and Nachtigal (2001) tested, in mist chamber, the propagation of four clones of Green mombim through herbaceous cuttings and verified significant differences in the rooting percentage among the materials - values between 78 and $93 \%$.

Thus, the difference found in the rooting percentage of the cuttings of the clones of sweet potato is likely genetic, physiological and metabolic specific traits of each genotype as occurs also in different cultivars of guava trees, according to Zietemann and Roberto (2007) when producing plantlets of the plant in trays. Associated to this, low rates of rooting may happen due to a higher predisposition of such young cuttings for losing water.

However, in some species, the viable cutting production does not differ among the genotypes. In plum trees, Schwengber et al. (2002) have not found differences in the percentage of rooted cuttings studied in different containers, among them, the 128-cell Styrofoam strays.

With regard to the changes in the field ten days after the transplant (DAT), the clones were divided into four groups. All the groups have presented satisfactory results, since only one clone (1230) showed a final stand inferior to $90 \%$ in relation to the initial stand, when the mean was $98.1 \%$. Rós-Golla et al. (2010), with similarly methodology, observed survival rates of plantlets of two genotypes of sweet potato, seven days after the plantation, superior to $99 \%$. Islam et al. (2002) also found high survival percentage $(100 \%)$ after the plantation in field of two clones of sweet potato produced in trays, confirming the plantation viability of plantlets of sweet potato produced in trays.

\section{Conclusion}

Is technically viable the production of rooted mini-cuttings of sweet potato in trays.

\section{Acknowledgement}

Dr. João Bosco Carvalho da Silva, researcher of Embrapa Hortaliças, for the supply of branches for the formation of mother plants of the clones of sweet potato used in this work.

\section{References}

ALMEIDA, F. D. de; XAVIER, A.; DIAS, J. M. M. Propagação vegetativa de árvores selecionadas de Eucalyptus cloeziana F. Muell. por estaquia. Revista Árvore, Viçosa, v. 31, n. 3, p. 445-453, 2007.

BETANIN, L.; NIENOW, A. A. Propagação vegetativa da corticeira-da-serra (Erythrina falcata Benth.) por estaquia caulinar e foliar. Semina: Ciências Agrárias, Londrina, v. 31, n. 4, p. 871-880, 2010.

BRUNE, S.; SILVA, J. B. C.; FREITAS, R. A. de. Novas técnicas de multiplicação de ramas de batata-doce. Brasília: Embrapa Hortaliças, 2005. 8 p.

CUQUEL, F. L.; GRANJA, N. do P.; MINAMI, K. Avaliação do enraizamento de estacas de crisântemo (Chrysanthemum morifolium L.) cv. White Reagan 606 tratadas com ácido indolbutírico (IBA). Scientia Agricola, Piracicaba, v. 49, p. 15-22, 1992. Especial.

EMPRESA BRASILEIRA DE PESQUISA AGROPECUÁRIA - EMBRAPA. A cultura da batatadoce. Brasília: EMBRAPA, SPI, 1995. 94 p.

GONÇALVES, A. L.; MINAMI, K. Efeito de substrato artificial no enraizamento de estacas de calanchoe (Kalanchoe $x$ blossfeldiana cv. singapur, crassulaceae). Scientia Agricola, Piracicaba, v. 51, n. 2, p. 240-244, 1994.

HARTMAN, H. T.; KESTER, D. E.; FRED JR, T. D.; GENEVE, R. L. Plant propagation: principles and practices. New Jersey: Prentice Hall, 1997. 770 p.

ISLAM, A. F. M. S.; KUBOTA, C.; TAKAGAKI, M.; KOZAI, T. Sweetpotato growth and yield from plug transplants of different volumes, planted intact or without roots. Crop Science, Palo Alto, v. 42, p. 822-826, 2002. Available at: <http://crop.scijournals.org/cgi/content/ full/42/3/822>. Access: 02 sep. 2009. 
LIMA, R. L. S. de; SIQUEIRA, D. L. de; WEBER, O. B.; CAZETTA, J. O. Comprimento de estacas e parte do ramo na formação de mudas de aceroleira. Revista Brasileira de Fruticultura, Jaboticabal, v. 28, n. 1, p. 8386, 2006.

LUZ, P. B. da; PAIVA, P. D. de O; LANDGRAF, P. R. C. Influência de diferentes tipos de estacas e substratos na propagação assexuada de hortênsia [Hydrangea macrophylla (Thunb.) Ser.]. Ciência e Agrotecnologia, Lavras, v. 31, n. 3, p. 699-703, 2007.

MAYER, N. A.; PEREIRA, F. M.; NACHTIGAL, J. C. Propagação do umezeiro (Prunus mume Sieb \& Zucc.) por estaquia herbácea. Revista Brasileira de Fruticultura, Jaboticabal, v. 23, n. 3, p. 673-676, 2001.

MELETTI, L. M. M.; TEIXEIRA, L. A. J.; COELHO, S. M. B. M.; SACRAMENTO, B. M. M.; FOLTRAN, D. E.; SOARES, N. B. Propagação de frutiferas tropicais. Guaíba: Agropecuária, 2000. 239 p.

ONO, E. O.; RODRIGUES, J. D.; PINHO, S. Z. de. Estudo da influência da época de coleta dos ramos, no enraizamento de estacas caulinares de café (Coffea arabica L. cv "Mundo Novo"). Scientia Agricola, Piracicaba, v. 49, p. 29-35, 1992. Especial.

PIMENTA, M. R.; FERNANDES, L. S.; PEREIRA, U. J.; GARCIA, L. S.; LEAL, S. R.; LEITÃO, S. G.; SALIMENA, F. R.; VICCINI, L. F.; PEIXOTO, H. P. Floração, germinação e estaquia em espécies de Lippia L. (Verbenaceae). Revista Brasileira de Botânica, São Paulo, v. 30, n. 2, p. 211-220, 2007.

REGHIN, M. Y.; OTTO, R. F.; OLINIK, J. R.; JACOBY, C. F. S. Viabilidade do sistema de produção de mudas em bandejas em três cultivares de cebola. Ciência e Agrotecnologia, Lavras, v. 31, n. 4, p. 1075-1084, 2007.

RONCATTO, G.; NOGUEIRA FILHO, G. C.; RUGGiERO, C.; OLIVEIRA, J. C. de; MARTINS, A. B. G. Enraizamento de estacas herbáceas de diferentes espécies de maracujazeiro. Revista Brasileira de Fruticultura, Jaboticabal, v. 30, n. 4, p. 1094-1099, 2008.

RÓS-GOLLA, A.; SILVA HIRATA, A. C.; ARAÚJO, H. S. de; SANTOS, V. B. dos; NARITA, N. Multiplicação de material vegetativo de batata-doce em diferentes bandejas e produção de raízes. Apta Regional, Campinas, mar. 2010. Disponível em: <http://aptaregional.sp.gov. br/artigo.php?id artigo=733>. Accesso: 17 mar. 2010.

SALOMÃO, L. C. C.; PEREIRA, W. E.; DUARTE, R. C. C.; SIQUEIRA, D. L. de. Propagação por estaquia dos maracujazeiros doce (Passiflora alata Dryand.) e amarelo (P. edulis f. flavicarpa O. Deg.). Revista Brasileira de Fruticultura, Jaboticabal, v. 24, n. 1, p. 163-167, 2002.

SCHWENGBER, J. E.; DUTRA, L. F.; TONIETTO,
A.; KERSTEN, E. Utilização de diferentes recipientes na propagação da ameixeira através de estacas. Revista Brasileira de Fruticultura, Jaboticabal, v. 24, n. 1, p. 285-288, 2002.

TILLMANN, M. A. A.; CAVARIANI, C.; PIANA, Z.; MINAMI, K. Comparação entre diversos substratos no enraizamento de estacas de crotón (Codiaeum variegatum L.). Scientia Agricola, Piracicaba, v. 51, n. 1, p. 17-20, 1994.

ZIETEMANN, C.; ROBERTO, S. R. Produção de mudas de goiabeira (Psidium guajava L.) em diferentes substratos. Revista Brasileira de Fruticultura, Jaboticabal, v. 29, n. 1, p. 137-142, 2007. 